This item was submitted to Loughborough's Research Repository by the author.

Items in Figshare are protected by copyright, with all rights reserved, unless otherwise indicated.

\title{
Asking elaborate questions: focus groups and the management of spontaneity
}

PLEASE CITE THE PUBLISHED VERSION

http://onlinelibrary.wiley.com/doi/10.1111/1467-9481.00081/abstract

PUBLISHER

(C) Blackwell Publishing Ltd

VERSION

AM (Accepted Manuscript)

LICENCE

CC BY-NC-ND 4.0

\section{REPOSITORY RECORD}

Puchta, Claudia, and Jonathan Potter. 2019. "Asking Elaborate Questions: Focus Groups and the Management of Spontaneity”. figshare. https://hdl.handle.net/2134/9425. 
This item was submitted to Loughborough's Institutional Repository (https://dspace.lboro.ac.uk/) by the author and is made available under the following Creative Commons Licence conditions.

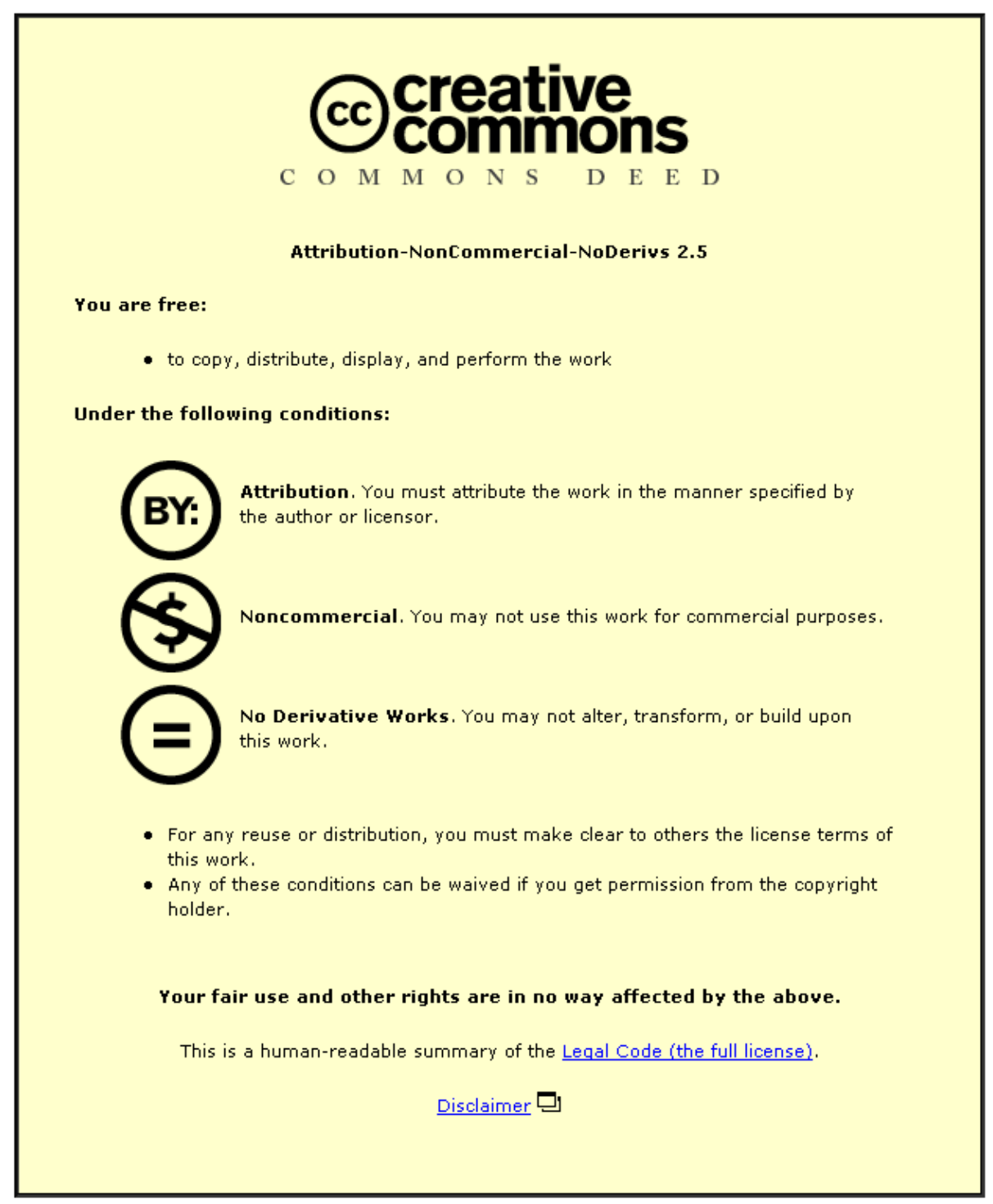

For the full text of this licence, please go to: http://creativecommons.org/licenses/by-nc-nd/2.5/ 


\section{Asking Elaborate Questions:}

\section{Focus Groups and the Management of}

\section{Spontaneity}

Claudia Puchta \& Jonathan Potter

Loughborough University

Published as:

Puchta, C. \& Potter, J. (1999). Asking elaborate

questions: Focus groups and the management of

spontaneity, Journal of Sociolinguistics, 3, 314-335. 


\begin{abstract}
This paper analyzes question formats in a corpus of German market research focus groups. In particular, it identifies and studies the use of 'elaborate questions' (questions which include a range of reformulations and rewordings). The analysis highlights three functions of such questions in focus groups (a) they are used to guide participants and head off trouble where the question type is 'non-mundane'; (b) they help secure participation by providing an array of alternative items to respond to; (c) they guide participants to produce a range of opinion relevant responses. More generally, they help manage a dilemma between the requirement that the talk should be both highly focused on predefined topics and issues, and at the same time spontaneous and conversational. The analysis provides a range of interactional evidence for the pragmatic role of these formats.
\end{abstract}

Keywords: question formats, focus groups, conversation analysis, institutional talk, discursive psychology of opinion, market research. 


\title{
INTRODUCTION
}

\author{
I, (.) uh, (.) now want to, (.) pester the \\ living daylights out of you a bit, in the hope, \\ that you, (.) will answer as spontaneously as \\ possible, (.) there's no wrong answer, there's \\ also no right answer, ((continues) $)^{1}$
}

This quote comes from the opening sequence of a German market research focus group. In standard introductions to focus group techniques moderators are advised to make similar statements. For example, Vaughn et al write:

This interview is not a test, nor should it in any way be viewed as a series of questions with right or wrong answers. Remember, we are very interested in what you think and feel. $(1996: 41,42))$

Our current paper focuses on the tension implied in this introductory statement and how it is managed through the construction of particular kinds of question. This is a tension, on the one hand, between the activity of 'pestering the living daylights' out of participants and, on the other, the ideal that group members should 'answer as spontaneously as possible'. Put another way, it is a tension between the licence to give answers that are 'neither right nor wrong' and a demand on participants to actually produce answers rather than 'I-don't-know's'. For moderators this means, on the one hand, having to provide a non-threatening and permissive environment and, on the other, working 
from a detailed question guide. More specifically, this paper considers the way this dilemma between an authoritarian and a laissez-faire concept of focus groups is evidenced in, and oriented to, through the design of the moderators' questions.

The paper has two basic goals. First, it is intended to provide an analytically based technical understanding of interaction in focus groups, centring on how questions are constructed and what is achieved by these constructions. Second, it will contribute to two emerging bodies of work: conversation analytic studies of talk in, and of, social institutional settings (Drew and Heritage, 1992) and to discursive psychological studies of opinions (Myers, 1998; Potter, 1998a).

Before addressing these questions, however, we will provide some brief background information on the way focus groups have developed and are understood in social science; thereafter we will introduce our analytic materials and approaches to focus groups in market research in general.

\section{Focused AND Spontaneous INTERACTION In Focus GROUPS}

As Morgan (1998) notes, the history of focus groups can be divided into three periods: the earliest work was carried out both by academic and applied social scientists. From World War II until about 1980, focus groups were almost exclusively used in market research. Most recently, focus groups have become a widespread research method and are used for example to assess health education and environmental messages, people's experiences of 
disease and health services, and the attitudes and needs of staff (Kitzinger, 1995).

According to Krueger 'a focus group is a carefully planned discussion designed to obtain perceptions on a defined area of interest in a permissive, nonthreatening environment' (1994:6). It is interesting to note that this definition contains a similar tension to the one mentioned above, between 'carefully planned' and 'permissive' (see also Agar and MacDonalds, 1995). Morgan (1998) draws attention to the abuse of the term focus group and excludes groups which are not focused because the moderator cannot keep the group focused and groups which do not engage in discussion. For Morgan, the 'hallmark of focus groups is their explicit use of group interaction to produce data and insights that would be less accessible without the interaction found in a group' (1997:2).

Both market researchers and social scientists claim the principal advantage of focus groups to be the interactive nature of their data, providing access to the participants' 'own language, concepts and concerns' (Wilkinson, 1998a:188; cf. Goldman and McDonald, 1987:17) or as Kitzinger puts it:

Group work also helps researchers tap into the many different forms of communication that people use in day to day interaction, including jokes, anecdotes, teasing, and arguing. (1995:299)

We might go as far and say that focus groups are considered to offer 'a slice of life'. But how 
can focus groups be simultaneously focused and more or less spontaneous and natural? Authors manage the tension between describing focus groups as a focused discussion which is nevertheless more or less spontaneous and natural in two different ways. Firstly, it is stressed in particular by the feminist focus group researchers such as Wilkinson that focus groups are just not focused in the sense that the moderator sets the agenda, but that the participants follow their own ones. Focus groups are considered as a relatively '"egalitarian"' method (1998b:330) as by the sheer number of participants involved, the power of the researcher is reduced. On the other hand, it might be possible that other authors will not consider these groups as being focus groups at all; see for example Morgan who emphasizes that groups in which the researcher does not take the role of directing the discussion are not focused enough for being called focus groups (1998:34). And Vaughn et al point to what they call another potential misuse during the conduct of the focus group:

A common misunderstanding about the conduct of focus groups is that they are 'loose' and not precise in the way they are conducted and organized. Although the interview often gives the impression of being causal and 'informal' conversation, it is actually the result of a highly planned session with clearly identified objectives and carefully composed questions. (1996:151) 
Secondly some authors claim a focus group can be both focused and spontaneous/natural because of a good question guide. Morgan writes:

Hence, when I train novice moderators, I pay as much attention to constructing a good guide as to managing the actual group dynamics. The reason is that an effective guide can produce a discussion that manages itself. (1997:48, emphasis added)

Krueger, moreover, stresses that specifically the questions themselves should appear spontaneous:

The moderator uses predetermined, open-ended questions. These questions appear spontaneous but are carefully developed after considerable reflection. The questions - called the questioning route or interview guide - are arranged in a natural, logical sequence. (1994:20)

Both the ingenious question guide and, particularly, the qualified moderator are considered as assets for running a smooth and well focused group. The moderator is the one who 'carefully and subtly guides the conversation back on target' (Krueger, 1994:101) if participants offer irrelevant topics. Throughout the literature the importance of the moderator is stressed.

To sum up, then: manuals stress both a focused discussion and spontaneous participant interaction. Some manuals point either to the quality of the question guide and/or the qualities of the 
moderator, which/who manages a smooth and nevertheless focused discussion. All manuals give lengthy descriptions of moderator qualities. A good moderator seems to be able to be both: participantcentred and participant-controlling. However, the research quoted here does not give us any answer on how exactly the moderator manages this tension.

This paper will analyze interaction in market research focus groups and will focus especially on how questions are asked by moderators. We will describe the phenomenon of 'elaborate questions' and will suggest that these questions offer the participants an array of question components to which they can respond to. The question design itself manages the tension between focusing participants on a certain topic while simultaneously offering them the choice to which specific question component 'spontaneously' to respond to.

Apart from allowing focus group members to select different question components for their answer, elaborate questions seem to have other functions too: they illustrate specific (and slightly esoteric) market research tasks and they secure participation by providing a maximal number of stimuli; we will discuss these functions in turn. But, first of all, we will describe our analytic materials and the use of focus groups in market research. 


\section{AnAlytic Materials}

In the following we will analyze market

research focus groups. Calder (1977) describes three different approaches to focus groups - the exploratory, the clinical and the phenomenological approach. Whereas the exploratory approach seeks to obtain what calder calls 'prescientific knowledge' (1977:355) in areas that are relatively unknown to the researcher, the clinical approach seeks 'quasiscientific explanations' (1977:355) and is based on the premise that the real causes of behaviour must be discovered (and can be discovered) through the clinical judgement of trained analysts.

For us the most interesting approach is the phenomenological one, as this seems to be the most common one in market research. As marketers usually belong to other social groupings than the target groups, focus groups are considered as a way of bridging the social gap and to 'experience' a 'flesh and blood' consumer (Calder, 1977:358). The logic of the phenomenological approach dictates that the researcher must share the experience of consumers, that $(\mathrm{s})$ he must be somehow personally involved with them. Focus groups should not only transport the experience of consumers, but the 'experiencing of the experience of consumers' (1977:360).

The focus groups of our sample were mainly conducted in order to give advertising people and product managers the possibility to experience the experience of smokers (from behind the one-waymirror). We are not aware of any published examples of market research focus group transcripts. How 
typical is our data of current focus group practice? This is not easy to say precisely. The moderators are more directive than some of the social science approaches mentioned above. What we can say is that the market research department of the company who paid for the focus groups used here is endowed with an above-average budget, runs about two hundred focus groups a year (at a cost of something like two thousand pounds each), and works with a broad range of market research institutes and focus group moderators. It is hard to make a stronger claim to generalizability as there are no other published examples of market research focus groups. However, as we have used a sample of focus group tapes from a company which orders large numbers of focus groups, and works with many different institutes, we are as confident as we can be that our results are at least typical of German market research focus groups.

Market research focus groups are routinely video-recorded. A sample of eight focus group tapes run by six different moderators was used in this study. These were selected as satisfying the following criteria:

- They used a range of different moderators;

- The moderators varied in their skill (judged by the head of the market research department) ;

- Some of the groups covered broad and some narrow topics.

Each focus group lasted for ninety minutes or more; the number of participants varied from seven to eleven. We transcribed two focus groups from beginning to end, segments of thirty minutes from 
six focus groups and the opening sequence from every focus group, making altogether more than six hours of transcribed talk. Further transcript was made from the video as needed. Out of six moderators in the materials four were male and two were female; this broadly reflects current employment patterns in the area. To provide further information about the moderators' characteristics, we gave them transcript pseudonyms which reflect their sex. In all groups, about half of the participants were female. As participants are chosen to reflect the target group of the discussed cigarette brand, only one focus group consisted of middle-aged participants, all the others consisted of 'young' smokers - from the age of eighteen until about twenty-eight.

The focus groups are conducted in German and the transcripts are translated into English; all translations are checked by a bilingual English speaker. The analysis was done on the German original, but for presentation purposes we will use the English translation. We discussed from case to case, how best to transfer pauses and characteristics of speech production such as emphasized sounds from the German original to the English translation.

\section{ANALYSIS}

\section{ELABORATE QUESTIONS I: GUIDING UNDERSTANDING OF 'NON- MUNDANE' MARKET RESEARCH QUESTIONS}

In our market research focus group data question and answer sequences are pervasive. Krueger 
recommends that questions should be limited to a single dimension, otherwise moderators 'may inadvertently include words that they think are synonyms but that participants see as entirely different concepts' (1998:4). Furthermore he cautions against adding 'a second sentence, phrase that supposedly amplifies the question' for this may confuse the respondents 'by introducing another dimension' (1998:4). In contrast to this injunction, in our materials rewordings and reformulations of questions are pervasive; in our corpus questions are routinely asked in an 'elaborate way'.

Krueger gives examples of questions from question schedules to be administered within groups:

- What does the word violence mean to you?

- If you could do one thing to reduce violence in your community, what would it be? (1998:94)

(Remember that these are not actual questions used in actual groups.) Now compare these questions with the arrowed question asked in the following extract from our data. Mod. is the moderator; participants are shown as P1 and P2; cigarette brands are pseudonomized as capital cities. ${ }^{2}$

(1) Mod.: Tom; source: Stansted8,29; video: 10:02

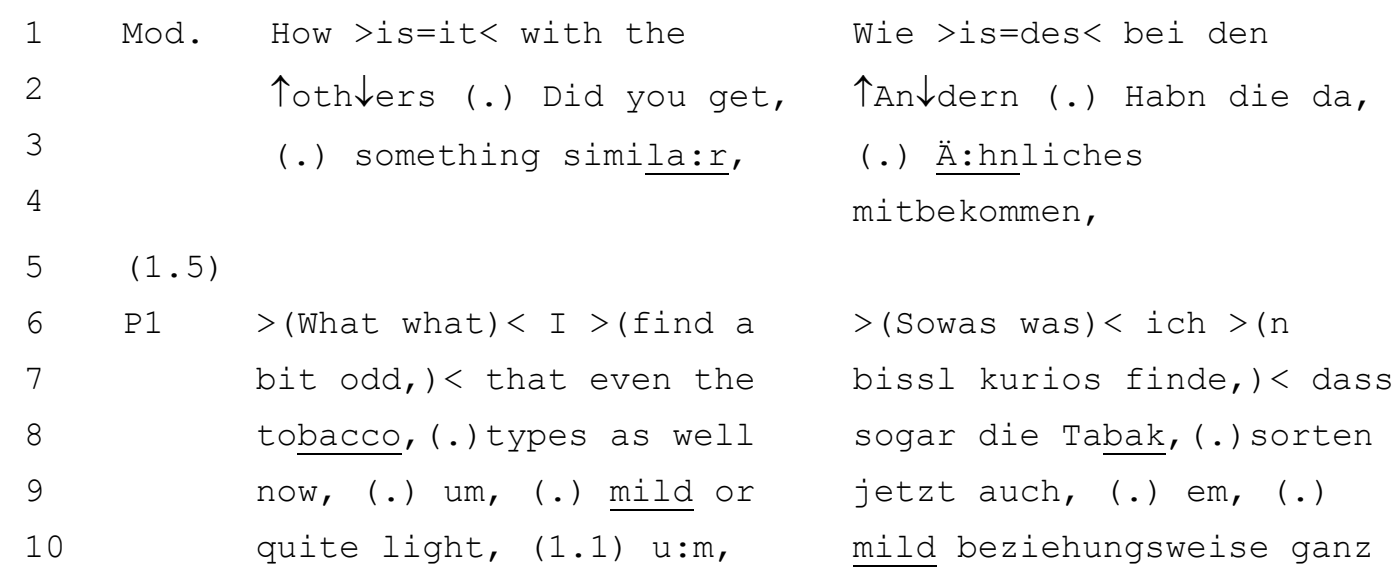




\begin{tabular}{|c|c|c|c|}
\hline 11 & & (.) switched over, =well, & light, (1.1) e:m, (.) \\
\hline 12 & & (.) for example, (.) & umgestiegen sind,=also, \\
\hline 13 & & Madrid, (.) or, (.) & (.) zum Beispiel Madrid, \\
\hline 14 & & Belfast, $=$ & (.) oder, (.) Belfast, $=$ \\
\hline 15 & Mod. & $=\mathrm{Hm} \mathrm{mm}$ & $=\mathrm{Hm} \mathrm{mm}$ \\
\hline 16 & $\mathrm{P} 1$ & Well you get it, (xxxxxxx) & Kriegt man ja, (xxxxxxx) \\
\hline & & (.7) quite lights, & (.7) ganz leichten, \\
\hline 18 & Mod. & $\mathrm{Hm} \mathrm{mm},=$ & $\mathrm{Hm} \mathrm{mm},=$ \\
\hline 19 & $\mathrm{P} 1$ & $=(\mathrm{x} \times \mathrm{x})$ & $=(\mathrm{x} x \mathrm{x})$ \\
\hline & & [tobaccos, & [Tabake, \\
\hline & & {$[\mathrm{Hm} \mathrm{mm},(.) \mathrm{hm} \mathrm{mm,} \mathrm{]}$} & {$[\mathrm{Hm} \mathrm{mm},(.) \mathrm{hm} \mathrm{mm,} \mathrm{]}$} \\
\hline & $(2.7)$ & & \\
\hline 23 & Mod. & Well how would you kind of & Wie würden Sie denn so \\
\hline & & generally (1.2) & allgemein, (.) die Rolle \\
\hline 25 & & assign,=classify, (.) the & der, Dublin da so, (1.2) \\
\hline & & role of the, Dublin, (.7) & zuordnen,=einordnen, (.7) \\
\hline & & have they followed a & haben sie nen Trend \\
\hline & & 个trend, $=$ uh, (.) >how would & mitge $\uparrow$ ma: cht, $=e h,()>$. wie \\
\hline & & $\overline{\text { you er },}<(1.7)$ describe & würden Sie da, $<(1.7)$ die \\
\hline & & the Dublin, =how has it, & Dublin beschreiben, =wie \\
\hline & & (1.0) well regarding this & hat die sich, (1.0) bei \\
\hline & & development $\uparrow$ now: (.8) to & dieser Entwicklung $\uparrow$ so: \\
\hline & & ultra个light, (.9) well & (.8) hin zum \\
\hline & & where does this one stand, & Ultra个leichten, (.9) wie \\
\hline & & & steht die da so, \\
\hline 3 & $\mathrm{P} 2$ & Well I do $\uparrow$ think, that it & Also denke $\uparrow$ schon, dass \\
\hline & & has fol $\uparrow$ lowed the & die diesen Trend \\
\hline & & trend, =in so far as they & mitge $\uparrow$ macht \\
\hline & & went from the Dublin, (.) & haben,=insofern als sie \\
\hline & & first of all to Dublin & von der Dublin auf, (.) \\
\hline & & Stock $\uparrow$ holm, =and now they & Dublin Stock个holm zunächst \\
\hline & & also offer this 个oslo, & mal gegangen sind, =und \\
\hline & & (1.0) and I notice that, & jetzt diese 个oslo noch \\
\hline & & too, as a Dublin=I mean & anbieten, (1.0) und ich \\
\hline & & I've long been a Dublin=er & 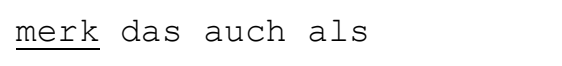 \\
\hline & & smoker, & Dublin=also ich hab lange \\
\hline & & & Dublin=halt geraucht, \\
\hline & & $\uparrow_{\mathrm{Hm}} \downarrow_{\mathrm{mm}}$, & $\mathrm{Hm} \downarrow \mathrm{mm}$, \\
\hline
\end{tabular}


The moderator starts by asking, how the participants would generally 'assign,=classify,' (line 25) the role of the cigarette brand Dublin. He rises his voice to signal that his turn has not come to an end yet and continues by adding 'have they followed a 个trend,' (lines 27+28). Another question component is latched onto the previous one ('=uh, (.) >how would you er, $<(1.7)$ describe the Dublin,'; lines 28-30). A next question component is similarly added, but left incomplete: '=how has it, (1.0) well regarding this development $\uparrow$ now: (.8) to ultra个light,'; lines 30-33). After a pause the moderator finally delivers another component ('well where does this one stand,'; lines 33+34).

Let us start by eliminating one initially plausible explanation for the complex structure of this question. Could the question components be added as the moderator pursues responses from reluctant participants (Pomerantz, 1984)? The evidence does not support this interpretation. In particular, note the way the first component ends with an upward intonation, and the next ones are latched to the previous ones, with continuing intonation again used in each case.

In four thirty minutes segments from focus groups run by different moderators, we found the following question frequencies, which contain more than one question component and which are delivered 'deliberately' ${ }^{3}$ by the respective moderator.

- Moderator Isabella: 14 elaborate questions

- Moderator Richard: 10 elaborate questions

- Moderator Tom: 9 elaborate questions 
- Moderator Sandra (judged by the head of the research department as the least skilled moderator):

7 elaborate questions.

Given the restricted space available, we can only analyze a limited number of these elaborate questions. Furthermore, we cannot say more about the structure and different elements. However, we have found that the degree of elaboration varies in our materials. Questions are most elaborate when the moderator nominates a new topic and when this topic is one that is unlikely to be discussed in everyday conversation. In these cases elaboration will include: (a) a prefatory statement; (b) added question components (e.g. reformulations of questions and candidate answers); (c) rewordings; (d) displays of delicacy (orienting to the intrusiveness of asking for views, the asking of hearably trivial questions, and the moderator's care for what participants are saying); and (e) non-vocal enactment (emphasising and dramatizing points with gestures). The main focus of the current paper is on components (b) and (c).

We also noted that more 'mundane' topic initial questions are delivered with prefatory statements, question reformulations and rewordings, but with less displayed delicacy and non-vocal enactment. When moderators pursue a topic with the group as a whole they miss out the prefatory statement, but elaborate with added components and rewordings. When they pursue a topic with individuals, moderators are more likely to use elaborate questions if a participant's answer has been problematic in some way. 
Minimal questions are also common in focus groups, but they tend to occur in three specific environments: (a) when the moderator is following up a topic with an individual who is answering in (what the moderator considers) an appropriate manner; (b) when eliciting background information from participants; (c) when questions relate to tasks which are not a direct part of the focus group.

Having outlined some of the broad patterning of question use in our materials, let us go back to the individual question components in Extract One. Tom asks first for a classification of 'Dublin' and following this delivers a question component which includes a candidate answer and could be answered with 'yes' or 'no' ('have they followed a 个trend,' ; lines $27+28$ ). In his answer, participant P2 uses this exact formulation: 'Well I do 个think, that it has fol个lowed the trend,' (lines 37-39). What might this question component be doing? One possibility is that it facilitates the answering of an abstract and unusual question - it is unlikely that participants discuss developments in the cigarette market like this when they are at home. One motivation for such question components, then is as illustrations of how participants should cope with 'non-mundane' questions.

The following pair of extracts supports this hypothesis. Coincidentally we have in our corpus the same question asked by the same moderator, Alan, in two different groups. It is a 'projective' question in which participants are asked to imagine the different varieties of a cigarette brand (the light, medium and strong version) as a family and to make 
suggestions of the role of the new family member (the light version) in this family. In one group the moderator's question causes hearable trouble; let us start with this extract.

(2) Mod: Alan; source: Blue17,645; video: 21:00

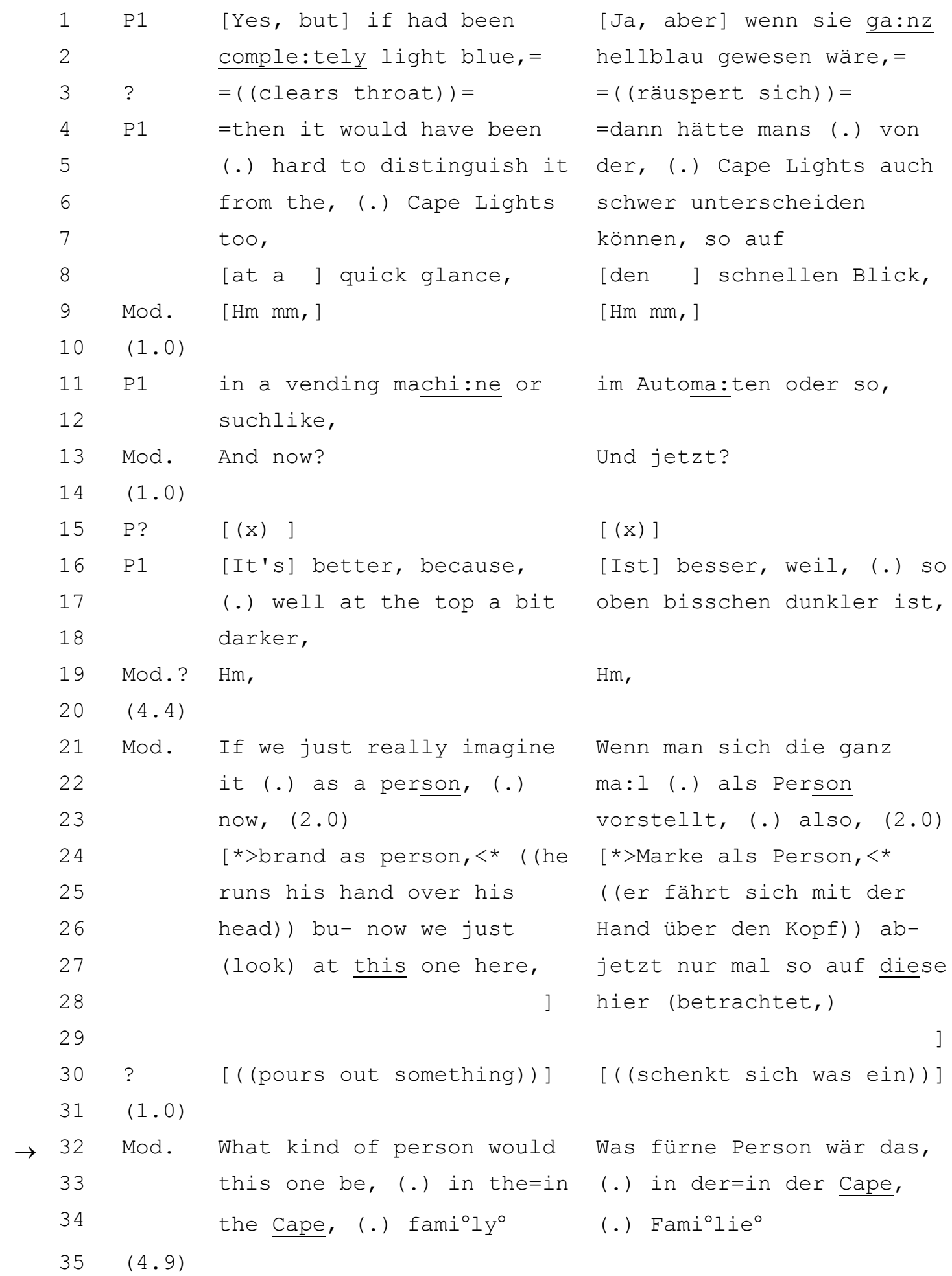




\begin{tabular}{|c|c|c|}
\hline P2 & $\left({ }^{\circ}\right.$ Person, don't know & $\left({ }^{\circ}\right.$ Person, weiss ich nicht, \\
\hline & $\left.x \times x \times x^{0}\right)=$ & $\left.x \times x \times x x^{\circ}\right)=$ \\
\hline Mod. & $=\underline{\text { Person! (.) It is }}$ & =Person! (.) Man kann sich \\
\hline & possible to imagine, (.) & doch auch, (.) Marken, \\
\hline & brands, (.) or, (.) & (.) oder, (.) Packungen \\
\hline & packets as per $\downarrow$ sons. & als Personen vorstel $\downarrow$ len. \\
\hline $\mathrm{P} 2$ & (I see, $x x x x x$ ) & $($ Ach so, $x \times x x x)$ \\
\hline P3 & The & Wit [zigste! (.) Pepp] \\
\hline & [funniest! (.) Most live] & igste! \\
\hline & ly! & \\
\hline P 4 & [Sprog! & [Jüngster Spross!] \\
\hline
\end{tabular}

Alan's question is followed by a long silence. P2, who sits next to the moderator seems to display his lack of understanding, after which Alan shouts emphatically '=Person!' (line 38) and that it is possible to imagine brands as persons.

In the following extract Alan asks another group also about the status of the new member of the existing brand family.

(3) Mod.: Alan; source: Blue19,18; video: 30:30

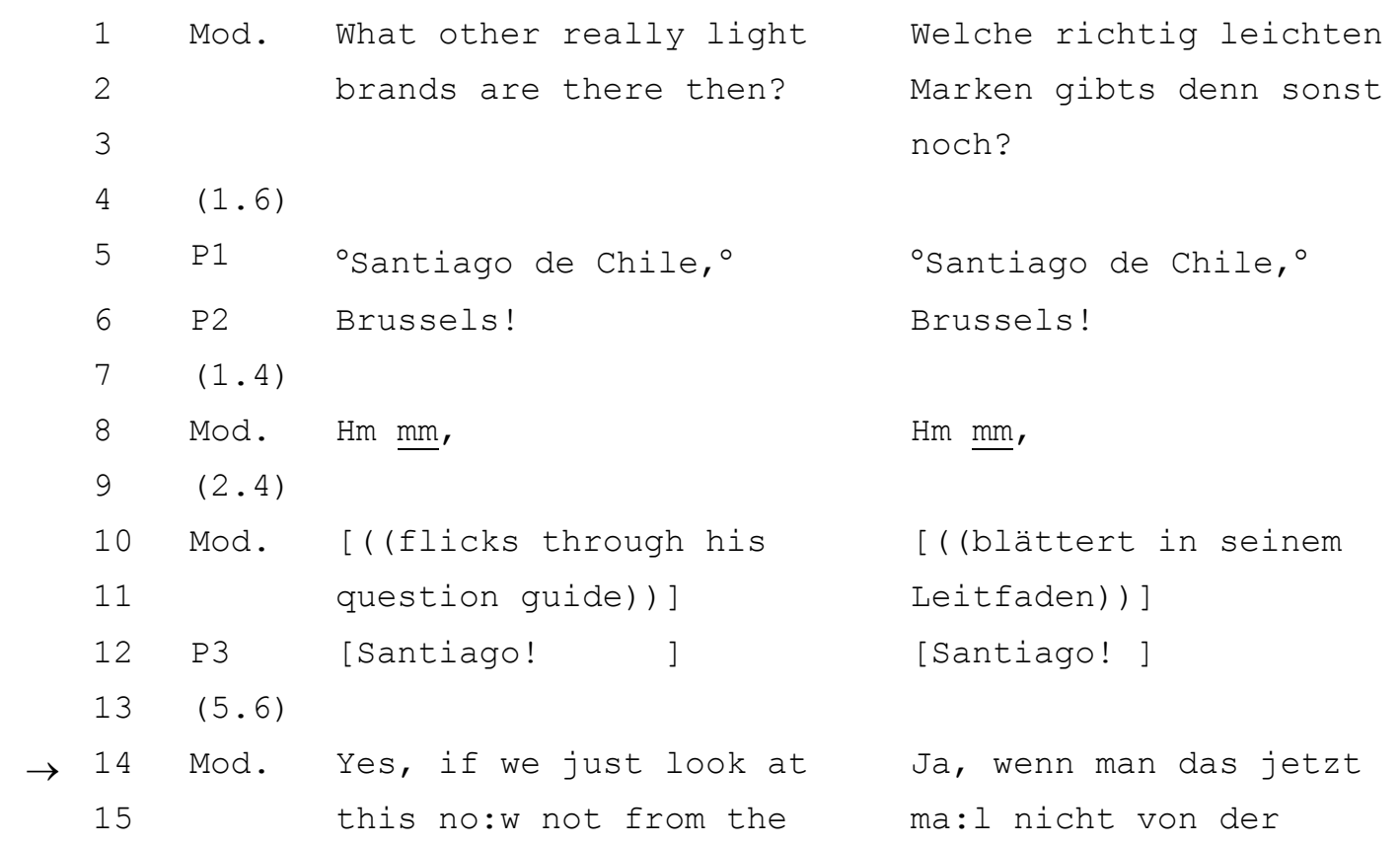




\begin{tabular}{|c|c|c|c|}
\hline 16 & & strength perspective, but, & Kräftigkeit, sondern dies \\
\hline & & well, this is just $\uparrow a$, & ist ja nur ei个ne, (1.6) \\
\hline & & (1.6) variant or a member, & Variante oder ein \\
\hline & & $(1.6)$ of the, $(.7)$ & Mitglied, (1.6) der, (.7) \\
\hline & & existing Cape family=>if & bestehenden Cape- \\
\hline & & we just (1.0) imagine & Familie=>wenn man sich das \\
\hline & & this, < as a family. (1.7) & mal< als Familie, (1.0) \\
\hline & & What kind of $a,($.$) family$ & vorstellt. (1.7) Was ist \\
\hline & & member ${ }^{\circ}$ is this ${ }^{\circ}$ (.8) Can & denn das für ein, (.) \\
\hline & & {$[$ wwell 1} & Familien ${ }^{\circ}$ mitglied. ${ }^{\circ}(.8)$ \\
\hline & & & Kann man \\
\hline & & & [rruhig \\
\hline & $\mathrm{P} ?$ & [((clears throat) )] & [((räuspert sich)) ] \\
\hline & Mod. & be pe:rsons, and how could & Perso:nen sein, und wie \\
\hline & & one=which characteristics & kann man=welche \\
\hline & & could one give this, (.) & Eigenschaften könnte man \\
\hline & & new member of the, (.) & diesem, (.) neuen Mitglied \\
\hline & & family, (1.2) the & der, (.) Familie, (1.2) \\
\hline & & Copenhagen. & der Copenhagen geben. \\
\hline & $\mathrm{P} 4$ & It's the baby, & Ist das Baby, \\
\hline & $(.7)$ & & \\
\hline & Mod. & The baby. & Das Baby, \\
\hline & P4 & The male baby & Das männliche Baby ( (fährt \\
\hline & & $(($ continues $))$ & fort)) \\
\hline
\end{tabular}

In this case it is after the completed question that a participant offers 'It's the baby,' (line 35) .

Let us compare the two question deliveries which lead in one group to hearable trouble and in the other to a smooth transition to the next speaker. In Extract Two the moderator asks to imagine the brand as a person and to imagine what kind of a person this brand would be in the exisiting family. In Extract Three, however, where there is less trouble, the moderator introduces at first the brand as a member of the existing family. He then asks: 'What kind of a, (.) family member ${ }^{\circ}$ is 
this.' (lines 23+24) and adds after having left uncompleted two other statement or question beginnings: 'which characteristics could one give this, (.) new member of the, (.) family, (1.2) the Copenhagen.' (lines 30-34). In her non-delayed answer ('It's the baby,'; line 35) participant 4 addresses the first question component after the status of the new brand in the family. Note how the moderator offers a choice of two different questions and note also how he elicits more information about the 'baby' by echoing the participant's answer. In contrast to Extract Two Alan splits the question after the 'brand as person' up into two facets which seems to work as a 'foot in the door technique' as, when the participant addresses one facet, the moderator asks implicitly for addressing the other one. The question elaboration, then, can be understood as orienting to the subtle pragmatics of eliciting and guiding participation.

Like the moderator's question in Extract One the questions in Extract Two and Extract Three deal with 'non-mundane' topics on cigarette brands and trends on the cigarette market. In One the moderator specifies the original question in adding a candidate answer; in Three he provides alternative questions on how one can approach the topic under discussion. Where he fails to provide alternatives in Extract Two, he receives no answer. Complex question structures, which include more than one question component thus seem to be delivered when the moderator has to get participants working with marketing-oriented topics. However, as we will see in the next section, this is only one function of 'elaborate questions'. 


\section{ELABORATE QUESTIONS II: SECURING PARTICIPATION BY PROVIDING AN ARRAY OF ALTERNATIVE ITEMS}

In Extracts one and Three in the previous section moderators ask for very special information such as characteristics of a brand 'if it was a person'. The following extract deals with a less esoteric topic, but the moderator nevertheless asks the question in an elaborate way as he adds question components to the original question. Again the start of the elaborated question is arrowed.

(4) Mod.: William; source: 17A,556; video: 18:29

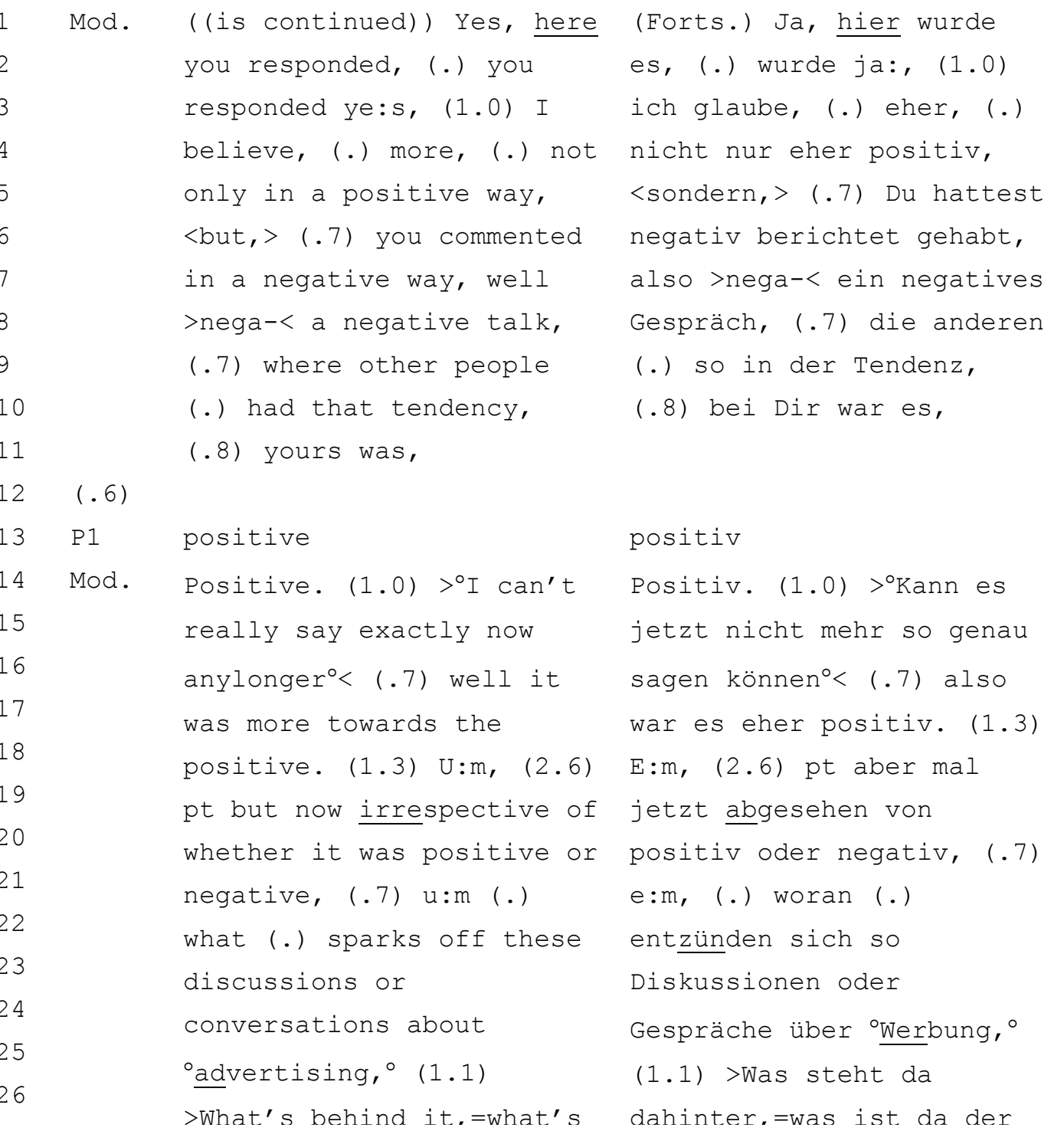




\begin{tabular}{|c|c|c|c|}
\hline \multicolumn{2}{|l|}{27} & \multirow{2}{*}{$\begin{array}{l}\text { >What's behind it, =what's } \\
\text { the cause, }<\text { (.) mostly (.) }\end{array}$} & \multirow{2}{*}{$\begin{array}{l}\text { dahinter, =was ist da der } \\
\underline{\text { Anlass, }<\text { (.) meistens, (.) }}\end{array}$} \\
\hline 20 & & & \\
\hline & & or often, (.) or & oder (.) oft, (.) oder \\
\hline & & sometimes, & manchmal, \\
\hline & \multicolumn{3}{|l|}{$(1.7)$} \\
\hline & \multirow[t]{5}{*}{$\mathrm{P} 2$} & Well, if it, you know, (.) & \multirow{5}{*}{$\begin{array}{l}\text { Na ja, wenns halt } \\
\text { irgendwie (.) gewisse } \\
\text { Gefühle, oder, em (.) (xx) } \\
\text { Emotionen (.) hervorruft }\end{array}$} \\
\hline & & creates (.) certain & \\
\hline & & feelings, or, um (.) (xx) & \\
\hline & & emotions somehow & \\
\hline & & & \\
\hline & Mod. & Aha, & \multirow[t]{2}{*}{ Aha, } \\
\hline & $(2 \cdot 3)$ & & \\
\hline & \multirow[t]{7}{*}{ P3 } & These are also almost & \multirow{6}{*}{$\begin{array}{l}\text { Sind ja auch meistens } \\
\text { immer Sachen, die man halt } \\
\text { irgendwie in Erinnerung } \\
\text { behält. (.) sei es nun } \\
\text { positiv oder negativ, (.6) } \\
\text { also irgendwas Auffälliges }\end{array}$} \\
\hline & & always things, which one, & \\
\hline & & you know, keeps in one's & \\
\hline & & memory somehow. (.) be it & \\
\hline & & now positive or negative, & \\
\hline & & (.6) well something & \\
\hline & & distinctive ${ }^{\circ}$ at any rate. ${ }^{\circ}$ & auf ${ }^{\circ} j e d e n$ Fall immer. ${ }^{\circ}$ \\
\hline & & & \\
\hline
\end{tabular}

Note first of all how, when William asks what sparks off conversations about advertising, he adds quickly:

>What's behind it, =what's the cause, < (.) mostly

(.) or often, (.) or sometimes, (lines 26-29).

The moderator presents the question in different forms and attaches a variety of options to the last component which state precisely when the cause is worth mentioning: 'mostly', 'often' or 'sometimes'. Let us look first of all at this part of this complex question. The listing at the end of the question is close to the textual form of a survey questionnaire. For example, an interviewee in a questionnaire study might be asked if (s) he buys cigarettes at the supermarket checkout most of the time, some of the time or never. The form is a menu 
of multiple choices where one must be selected. However, William, the moderator, does not offer a multiple choice question, but stretches the horizon when the reason which sparked off a discussion on advertising is worth mentioning - it can be mostly, often or sometimes. He thus does not exclude options, but he includes them all with the effect that the participant who answers first (P2) seems to summarize the three quantifying options ('Well, if it, you know, (.) creates (.) certain feelings, or, um (.) ( $\mathrm{xx}$ ) emotions somehow; lines 32-35) and the second (P3) combines 'mostly' and 'always' in his answer ('These are also almost always things, which one, you know, keeps in one's memory somehow.'; lines 39-42).

Let us go back to the three question components:

what (.) sparks off these discussions or conversations about ${ }^{\circ}$ advertising, ${ }^{\circ}$ (1.1.) >What's behind it, =what's the cause, $<$ ((continues)) (lines 22-27).

At a superficial examination it is not easy to to distinguish these three components. But consider P2's answer: 'Well, if it, you know, (.) creates (.) certain feelings, or, um (.) (xx) emotions somehow (lines 32-35). This answer closely matches the third question component, but could not easily have been given to the first one. The moderator thus provides a complex question which contains similar, but different stimuli, which the participants can address. As the moderator gives the participants the opportunity to address this or that facet of the question, he rises the probability of an actual 
answer production and minimizes the probability of silence or 'I-don't-know's'.

The following extract does not contain question reformulations, but it does contain a rewording. Let us see whether such a rewording might have a similar function to reformulation.

(5) Mod.: Sandra; source: Ausl,699; video: 32:50

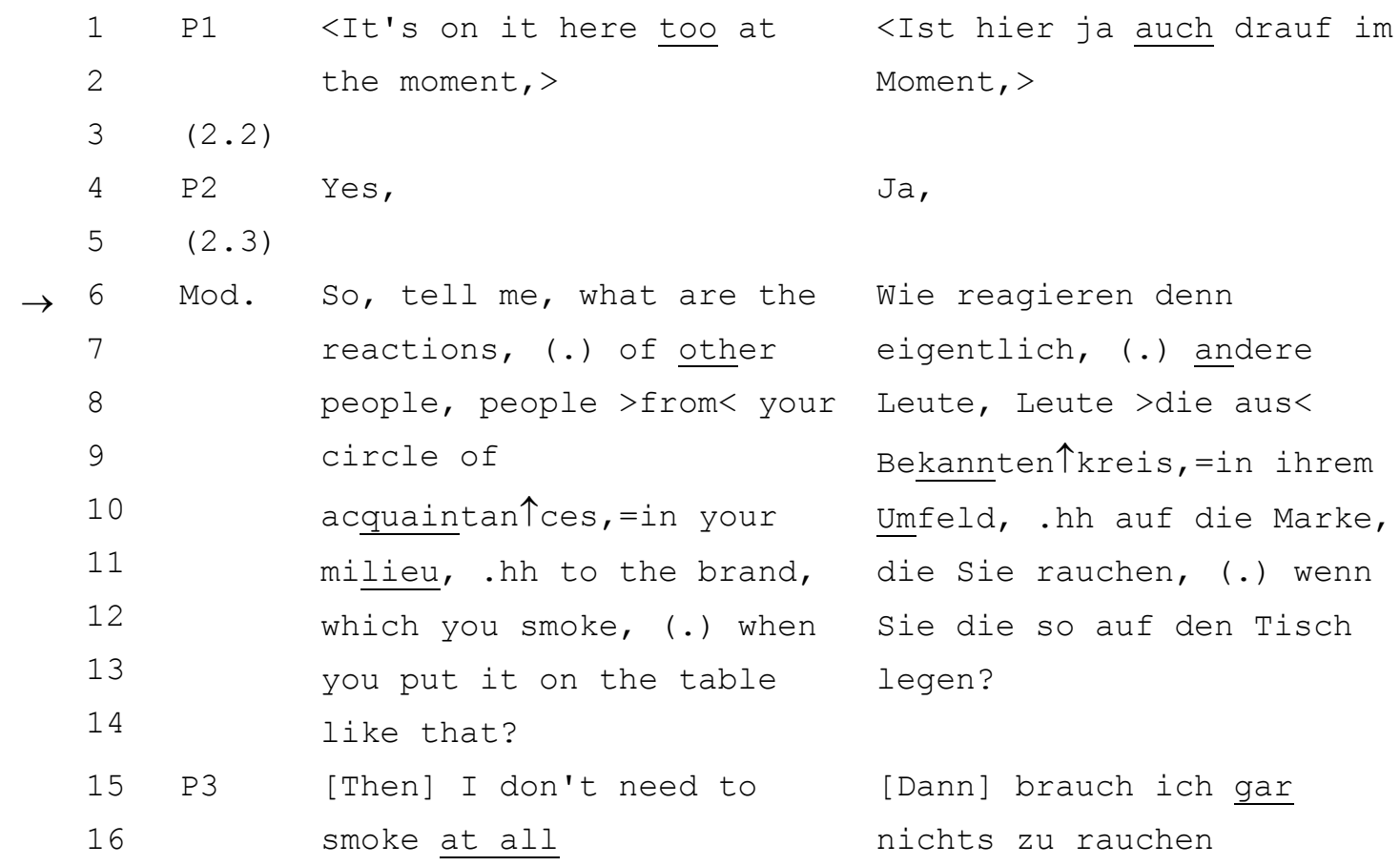

Sandra starts by asking for the reactions of other people regarding the participants' cigarette brand, when they put it on the table. She then further specifies 'people':

people >from< your circle of acquaintan $\uparrow$ ces, =in your milieu, (lines 8-11).

Whereas the notion of people in general might provoke 'I-don't-know's' (it may be difficult to think of anybody who is not included), when the 
moderator refers to people 'from your circle of acquaintainces' and to people 'in your milieu' a more manageable grasping is invoked. This again minimizes the probability of silence or 'I-don'tknow's'. Again the question elaboration has a direct pragmatic link to the elicitation of material."

We have seen in the last two extracts how another possible function of asking questions in an elaborate way is to secure participation by providing a portfolio of stimuli participants can address. Support for this idea can be seen in instances where the moderator asks questions in a 'minimal way' without adding question components or rewordings. Let us take for example the following fragment in which the moderator asks questions about a task the group members had just performed: marking the strength of three different varieties of one brand on a scale going from 'light' to 'strong' with the help of magnetic counters.

(6) Mod.: Isabella; source: Green17,488; video: $17: 00$

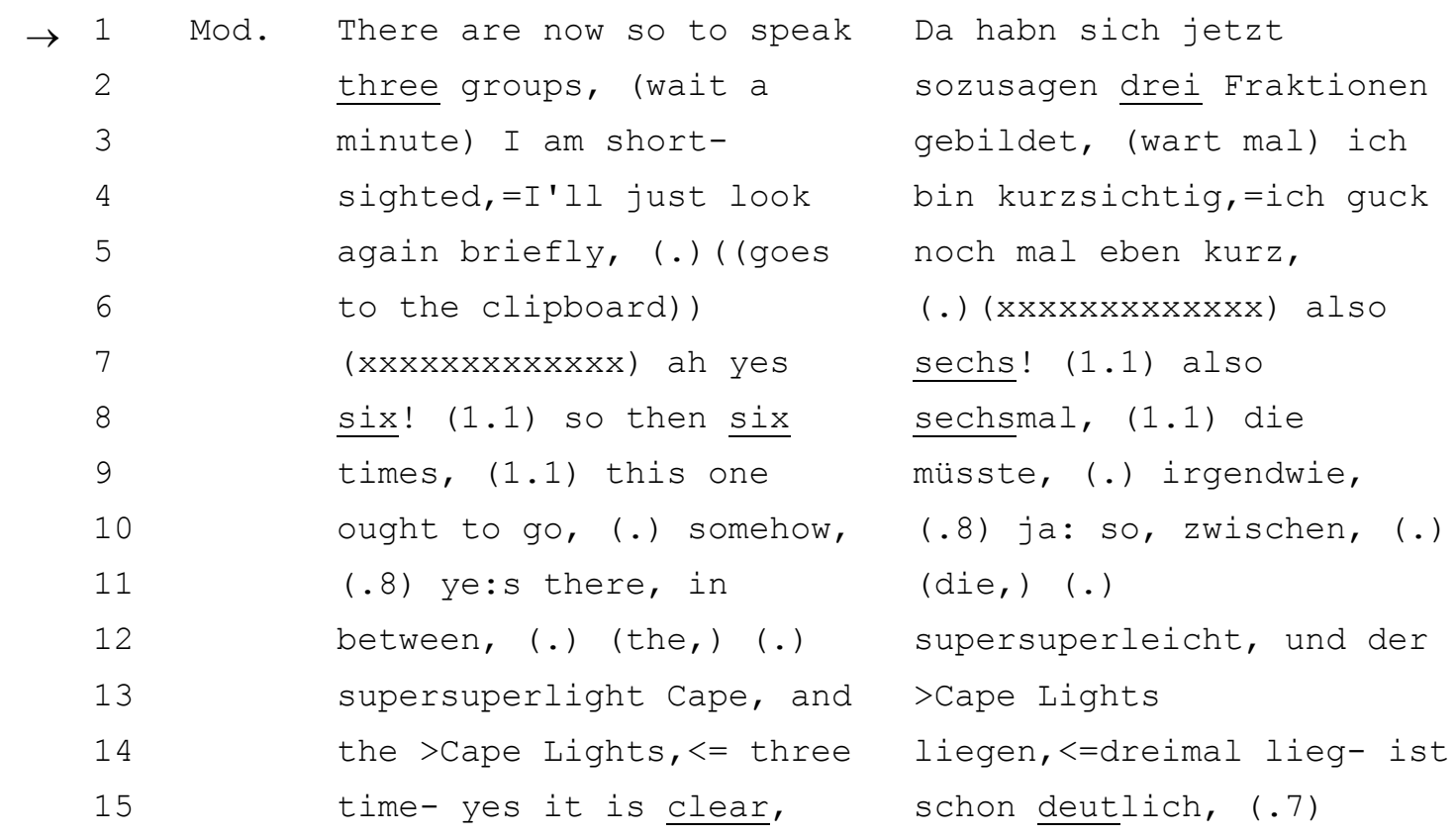




\begin{tabular}{|c|c|c|c|}
\hline 16 & & (.7) lighter than the Cape & leichter als die Cape \\
\hline 17 & & Lights, (.) and one man, & Lights, (.) und einer, \\
\hline 18 & & $(.7)$ or one $\underline{\uparrow_{w o m a n}},()$. & (.7) oder ei $\underline{\uparrow n e, ~(.) ~ s a g t ~}$ \\
\hline & & says finally, 'No, (.) & dann noch, 'Nee, (.) die \\
\hline & & this one is probably a & ist wahrscheinlich nen \\
\hline & & 个little $\downarrow$ bit 个stron $\downarrow$ ger, & 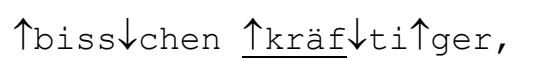 \\
\hline & & (.) than the Cape, (.) & (.) als die cape, (.) \\
\hline & & Lights.' (1.6) 个Um, (.) & Lights.' (1.6) 个Em, (.) \\
\hline & & I'm always of course & mich interessieren \\
\hline 2 & & interested, first of all & natürlich immer, erst die \\
\hline & & in the <outliers, $>$ (.) & $<\underline{\text { Ausreisser }},>()<.{ }^{\circ}$ wer \\
\hline 2 & & $<{ }^{\circ}$ who pinned that point & hat den Punkt da \\
\hline 2 & & there ${ }^{\circ}>$ ( (points to the & gesteckt? ${ }^{\circ}>$ ( (zeigt zur \\
\hline 3 & & clipboard)) & Tafel)) \\
\hline 3 & $()$. & & \\
\hline 3 & P1 & $\mathrm{ME} !$ & $\mathrm{ICH} !$ \\
\hline & $(1.4)$ & & \\
\hline 3 & Mod. & And, (.) uh, *how have you & Und, (.) eh, *wie bist Du \\
\hline 3 & & come to this decision?* & zu dieser Entscheidung \\
\hline 3 & & ((smiley voice)) & gekommen?* ( ( lächelnde \\
\hline 3 & & & Stimme)) \\
\hline & $\mathrm{P} 1$ & Yes, (.) I, (.) think, & Ja, (.) ich, (.) glaub, \\
\hline 3 & & that is, (.) something, & das is, (.) sonen, (.) \\
\hline 4 & & (.) like a cross, (.) & Zwischending da, (.) \\
\hline 4 & & between, (.) Cape and Cape & zwischen, (.) Cape und \\
\hline & & ${ }^{\circ}$ Lights,${ }^{\circ}=$ & Cape ${ }^{\circ}$ Lights, ${ }^{\circ}=$ \\
\hline
\end{tabular}

Note how the question about who positioned a certain point on the scale is asked in a straightforward manner:

$<^{\circ}$ who pinned that point there ${ }^{\circ}>$ (lines $\left.27+28\right)$.

And note also how the moderator's follow up question is similarly asked in a minimal fashion:

And, (.) uh, *how have you come to this decision?* ((smiley voice)) (lines 34-36). 
In contrast to the extracts we studied previously, the moderator does not provide a portfolio of stimuli for participants to address. Nevertheless P1 provides an immediate answer. One possible function of asking questions in a complex way is to secure participation. The moderator in the above extract, however, treats the participation as guaranteed. The moderator treats as unproblematic tasks such as asking the group for information which can be given with the help of an one-word-sentence or even non-vocally by rising the arm ('< ${ }^{\circ}$ who pinned that point there ? $^{\circ}{ }^{\prime} ;$ lines $27+28$ ) and asking a group member who volunteered already an answer for further details, that is for her 'motives' in pinning the chip in the way she did it.

To sum up, then: moderators secure participation by offering a portfolio of stimuli for participants to address. When questions are asked in a minimal way, members' participation is displayed as unproblematic. Although we have etablished the link between a portfolio of stimuli and group members' participation we are not able to fully exclude a further possible role for this question design. The delivery of such an array of items could help secure participation by providing members time for reflection which may enable them to come up with topics or answers. Whether this plays some role in the pragmatic effectiveness of elaborate questions (and we are not convinced it does) it complements rather than excludes the account we have developed in this analytic section.

In the next section we will use other minimal questions as a starting point for developing a third 
hypothesis on the function of elaborate questions in market research focus groups.

\section{ELABORATE QUESTIONS III: MANAGING OPINION PRODUCTION}

Moderators stress that, although they may be tenacious in their questioning ('I... want to... pester the living daylights out of you'), there is no

'wrong answer, there's also no right answer' (see the moderator's opening remarks quoted at the beginning of our paper). This raises the issue of whether elaborate questions are a way signalling that there are a range of different but nevertheless appropriate answers? Or, looked an another way, does a minimal question signal that a single appropriate answer is required?

A careful check of the videotapes showed that moderators ask minimal questions when they require participants to reveal themselves by putting their hands up (see the previous Extract Six) and they employ simple wh-questions when in dialogue with a single participant (see also the previous Extract). There are, however, exceptions. We identified a very small number of minimally asked questions $(n=7)$ when the moderators are neither engaged in a dialogue with an individual particpant nor in survey-like questioning such as 'Who voted for this option?' or 'Who knows the brand $x$ ?'.

Following a tradition in conversation analysis, these deviant cases were not considered as a 'nuisance, but a treasure'(Peräkylä, 1997:212) . Deviant cases can lead to a reconceptualization of the initial hypothesis. They can, however, also 
provide additional support for the initial claim (Heritage, 1988). In our study we consulted the small corpus of deviant minimal questions to further explicate the function of elaborate questions. Given the space, we will focus on one particularly revealing example.

The following fragment deals with an 'accident' in which the moderator drops two cigarette packets he has been holding before completing his question:

(7) Mod.: Richard; source: LondonB, 1282; video: $46: 00$

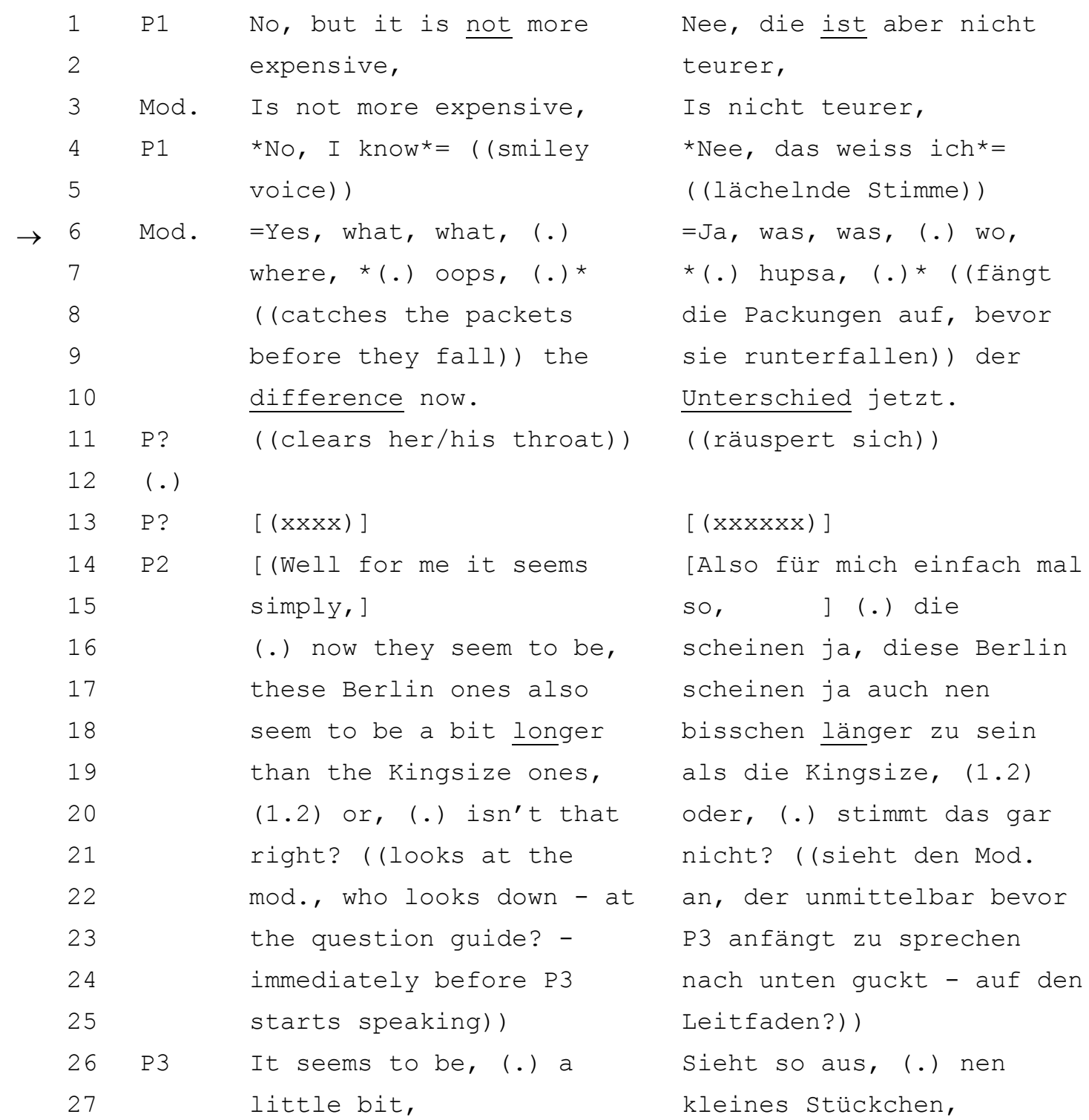


We do not know how Richard might have completed the question if he had not been distracted by the falling packets; we do not know either whether he might have added another question component asking about the difference between the two packets. In any case, the question as it stands is a straightforward minimal one about the difference between the packets and cigarettes under discussion:

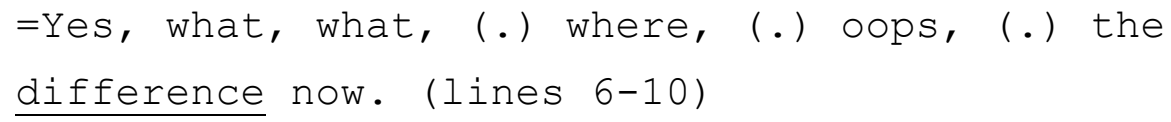

P2 treats the moderator's question as one which requires a 'right' answer and displays his uncertainty as he provides the correct answer. After a very hesitantly produced assessment (' [ (Well for me it seems simply,] (.) now they seem to be, these Berlin ones also seem to be a bit longer than the Kingsize ones,'; lines 14-19), the participant pauses for 1.2 seconds. As the moderator does not confirm the participant's statement, but displays 'silent recipiency' (see Puchta and Potter, 1998), P2 asks explicitly whether his assumption is correct - a question which is not answered by the moderator but by another participant.

The point here is that the moderator's (accidental?) minimal question is heard as an exam question which requires one answer - the correct answer, which the participant attempts to provide. The moderator's question seems to be understood as a factual question such as 'what is the capital of x?'. The participant orients to the exam character of the question by producing hesitation which occurs 
in 'inauspicious environments' (Drew and Holt, 1988; Wooffitt, 1989) where there is a strong possibility of rejection or disapproval of one's talk.

Let us turn from this deviant case to another typical elaborate question where the moderator provides an array of question components.

(8) Mod.: Richard; source: LondonB; video: 27:50

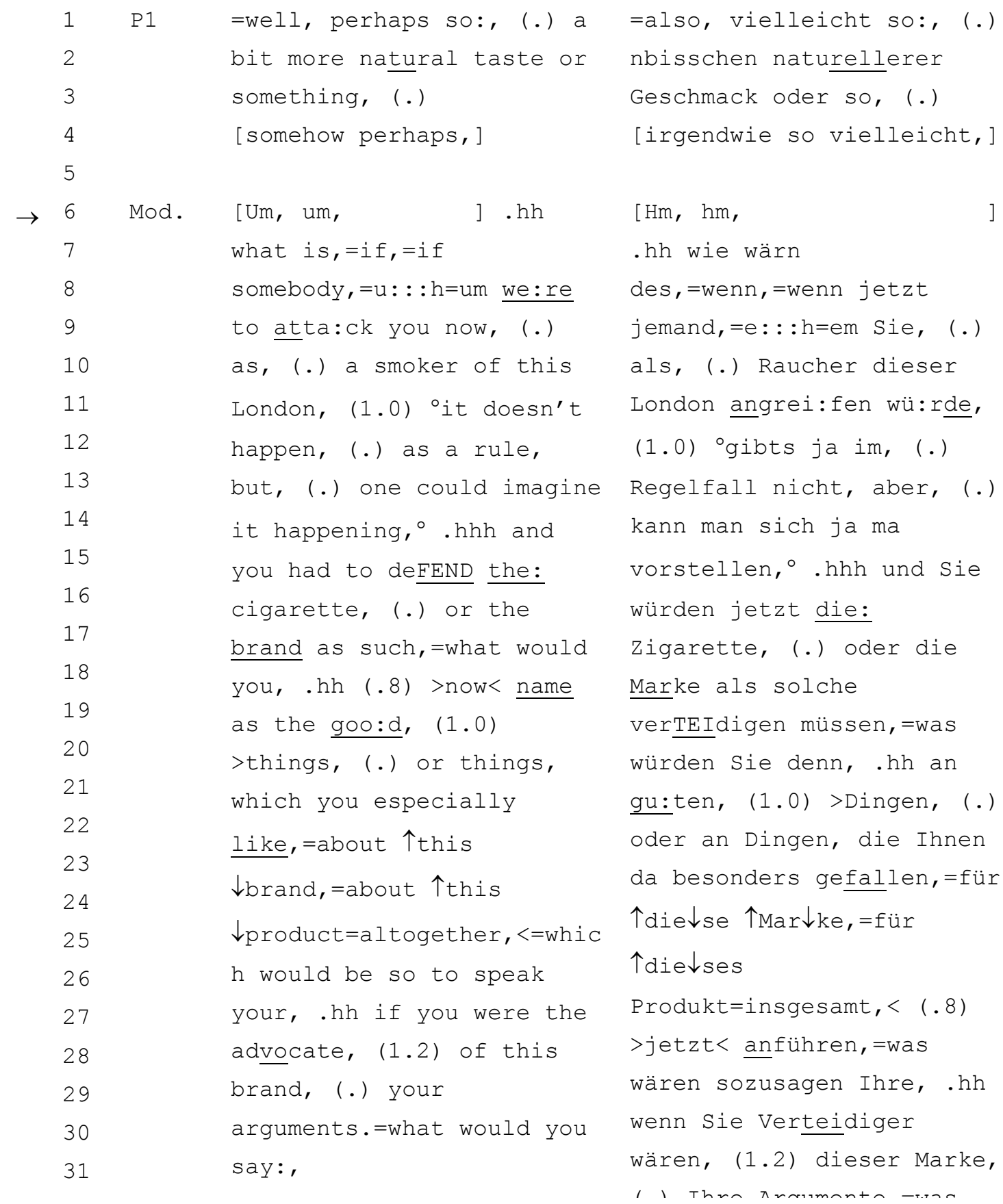


32

33

34

35

36
P3

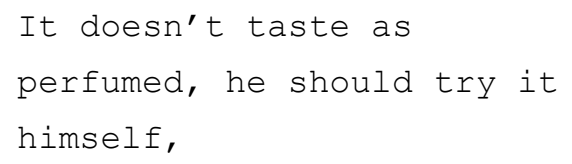

(.) Ihre Argumente.=was

würden sie da sagen so:,

Die schmeckt nicht so

parfümiert, er soll sie

selber probieren,

Following our analysis up to now, we see the functions of the different question components in lines 6-31 both as a guide in the understanding of a non-mundane market research question and a device for securing participation by providing an array of alternative items.

The comparison of Extract Eight with the deviant case points to a third function. In not simply asking 'how would you defend this brand?', but in reformulating the original question, the moderator displays that he is not after one answer. In providing a question portfolio, the moderator shows that there is more than a single answer. Offering an array of questions is a display of being interested in an array of answers. It might be argued that the obvious business at hand in focus groups is the production of opinions and that opinion production is facilitated through asking both minimal and elaborate questions. However, we have tried to show that by asking in an elaborate way the questioner orients to the difference between factual questions and opinion eliciting questions in an environment where participants may need to be reminded that the questions being asked are not just classroom questions. 


\title{
Discussion: Elaborate Questions AND the Production OF Spontaneous and VARIABle OpINIONS
}

\author{
In this paper we have tried to show how \\ elaborate questions in focus groups are organized in \\ ways which provide the kinds of answers that focus \\ group moderators require. In particular, they have \\ three roles. First, they are used to guide the \\ responses made by participants, and head off \\ trouble, when the question is likely to be \\ unfamiliar in everyday interaction (such as \\ 'projective' questions about the family associations \\ of cigarettes). Second, they help secure \\ participation by providing participants with an \\ array of alternative items to respond to. Third, \\ they provide guidance in producing the kinds of \\ responses that are appropriate to market research \\ reports and to the company representatives and \\ advertising people who may view the sessions from \\ behind one-way mirrors. \\ Elaborate questions may appear clumsy or \\ confusing when considered by abstract or strictly \\ grammatical criteria, and when compared to the \\ (cleaned up) questions which appear in focus group \\ manuals (see, for example, Krueger, 1998). Yet we \\ have shown how various features of question \\ elaboration can have a pragmatic motivation in doing \\ three 'jobs' at the same time.
}

Searle has made a distinction between 'real' and 'exam' ${ }^{5}$ questions:

In real questions the speaker wants to know (find out) the answer; in exam questions, the 
speaker wants to know if the hearer knows. (1969:66)

Focus group questions do not fall neatly into either of these categories. There are both real questions and exam questions in our corpus: one moderator asks for example 'What are you after?' when two participants talk with each other (and the answer is 'A bottle-opener.') and another asks which were the first light cigarette brands on the market. Both questions are asked minimally and aim at one correct answer; the first is a real question, the second an exam question. However, the elaborate questions we have studied do not require one specific answer, but answers that address one or more of the question components. Answers of this kind are treated by moderators as providing opinions.

We started our analysis by emphasising the moderator's dilemma between focusing the members' talk on a certain topic and eliciting spontaneous conversation. The different elements of elaborate questions help them meet this task. The portfolio of question components gives the participants the choice to spontaneously focus on one or more of the presented elements. Moreover, by offering a portfolio, elaborate questions discourage responses that are only 'right or wrong' answers. The art of the elaborate question is to delicately manage the production of the required social science entities opinions - while sustaining interaction that has a relaxed, spontaneous and unconstrained quality.

\section{NOTES}




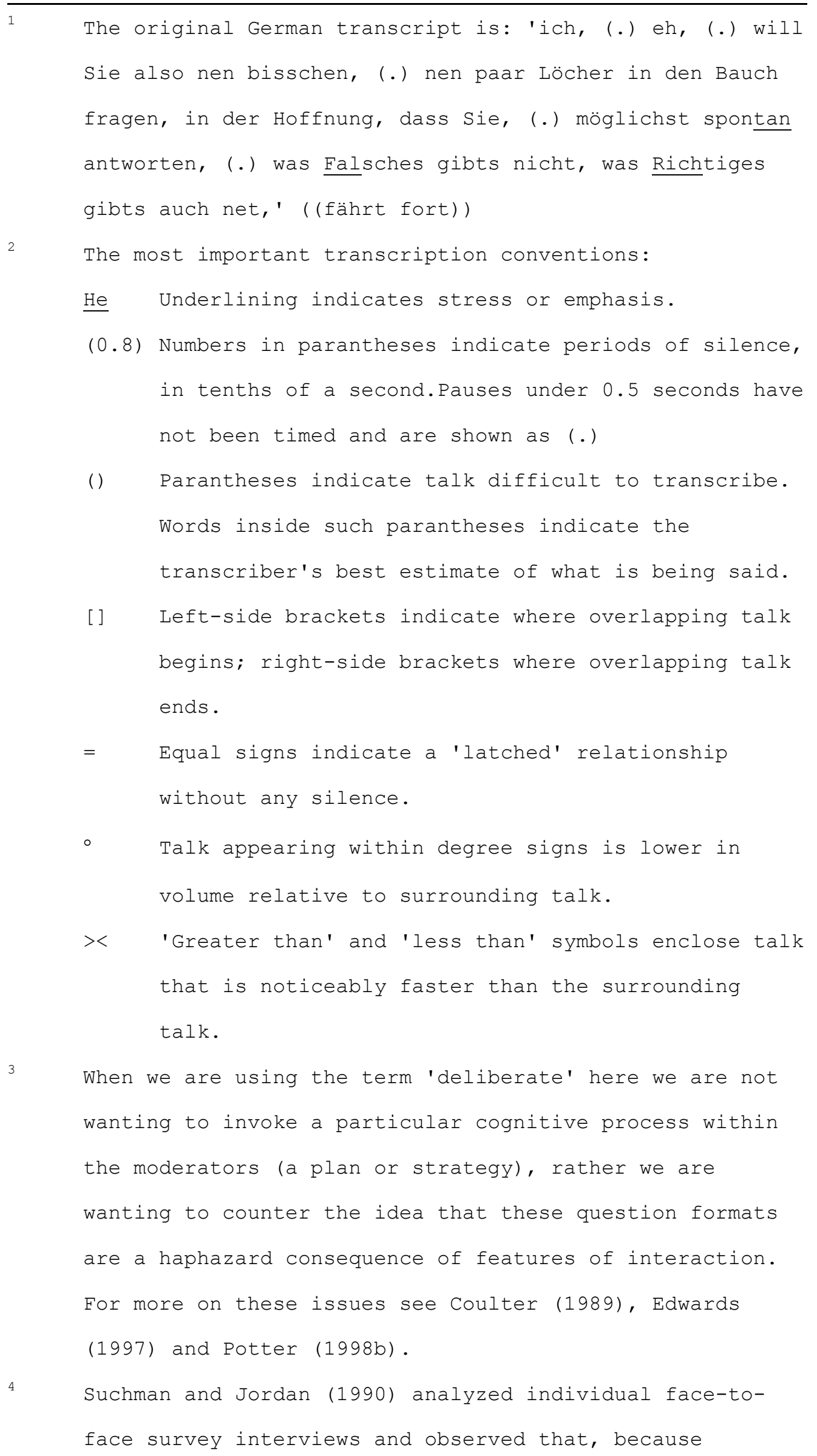


interviewers are trained not to redesign questions, questionnaires contain questions with exhaustive

specifications ('During those two weeks, did anyone in the family receive health care at home or go to a doctor's office, clinic, hospital or some other place ...'; 1990:233). Suchman and Jordan conclude that by providing such exhaustive specifications, interviewer and interviewee do not need to negotiate. Although we cannot exclude this motivation for focus group moderators, in contrast to a survey interviewer the moderator is not obliged to produce similar questions in different groups. See Extracts Two and Three where the moderator Alan asks the 'same' question, but each time formulates it in a slightly different way.

5 We do not want to endorse the hierarchy implied in Searle's distinction between proper and supplementary acts (see Derrida, 1977). For us, neither is more real; they are just different kinds of activity.

\section{REFERENCES}

Agar, Michael and MacDonalds, James. 1995. Focus groups and ethnography. Human Organization 54: $78-86$

Calder, Bobby J. 1977. Focus groups and the nature of qualitative marketing research. Journal of Marketing Research 14: 353-364.

Coulter, Jeffery. 1989. Mind in action. Cambridge: Polity 
Derrida, Jacques. 1977. Limited Inc. abc... Glyph 2: $162-254$

Drew, Paul and Heritage, John. 1992. (eds.) Talk at work: Interaction in institutional settings. Cambridge: Cambridge University Press.

Drew, Paul and Holt, Elizabeth. 1988. Complainable matters: The use of idiomatic expressions in making complaints. Social Problems 35: 398-417. Edwards, Derek. 1997. Discourse and cognition. London and Beverly Hills: California: Sage. Goldman, Alfred E. and McDonald, Susan Schwartz. 1987. The group depth interview: Principles and practice. Englewood Cliffs, New Jersey: Prentice Hall.

Heritage, John. 1988. Explanations as accounts: A conversation analytic perspective. In Charles Antaki (ed.) Analyzing everday explanation: A case book of methods. London: Sage. 127-144. Kitzinger, Jenny. 1995. Introducing focus groups. British Medical Journal 311: 299-302.

Krueger, Richard A. 1994. Focus groups: A practical guide for applied research (2nd ed.). Thousand Oaks, California: Sage.

Krueger, Richard A. 1998. Developing questions for focus groups. Thousand Oaks, California: Sage. 
Morgan, David L. 1997. Focus groups as qualitative research (2nd ed.). Thousand Oaks, California: Sage.

Morgan, David L. 1998. The focus group guidebook (Focus Group Kit, vol. 1). Thousand Oaks, California: Sage.

Myers, Greg 1998. Displaying opinions: Topics and disagreement in focus groups. Language in Society $27(1): 85-111$.

Peräkylä, Anssi. 1997. Reliability and validity in research based on tapes and transcripts. In David Silverman (ed.) Qualitative research: Theory, method and practice. Sage: London. 201220.

Pomerantz, Anita M. 1984. Pursuing a response. In J. Maxwell Atkinson and John Heritage (eds.) Structures of social action: studies in conversation analysis. Cambridge: Cambridge University Press. 152-163.

Potter, Jonathan. 1996. Representing reality: Discourse, rhetoric and social construction. London: Sage.

Potter, Jonathan. 1998a. Discursive social psychology: From attitudes to evaluative practices. European Review of Social Psychology $9: 233-266$. 
Potter, Jonathan. 1998b. Cognition as context (whose cognition?). Research on Language and Social Interaction 31: 29-44.

Puchta, Claudia and Potter, Jonathan. (forthcoming). Silent recipiency in market research focus groups.

Searle, John R. 1969. Speech acts. Cambridge: Cambridge University Press. Suchman, Lucy and Jordan, Brigitte. 1990. Interactional troubles in face-to-face survey interviews. Journal of the American Statistical Association 85: 232-241.

Vaughn, Sharon, Schumm, Jeanne S., and Sinagub, Jane. 1996. Focus group interviews in education and psychology. Thousand Oaks, California: Sage.

Wilkinson, Sue. 1998a. Focus group methodology: A review. International Journal of Social Research Methodology 1 (3): 181-203. Wilkinson, Sue. 1998b. Focus groups in health research: Exploring the meanings of health and illness. Journal of Health Psychology 3(3): $323-342$. Wooffitt, Robin. 1992. Telling tales of the unexpected: The organization of factal discourse. Hemel Hempstead: Harvester Wheatsheaf. 
Claudia Puchta \& Jonathan Potter Department of Social Sciences, Loughborough University, Loughborough, Leicestershire, LE11 3TU

E-mail: J.A.Potteralboro.ac.uk Phone: 01509223384

Fax: $\quad 01509223944$ 